Andrew R. Xavier, MD

Ambooj Tiwari, MD, $\mathrm{MPH}$

Amit Kansara, MD

Correspondence \& reprint requests to Dr. Xavier: axavier@med.wayne.edu

\section{Angioplasty and stenting for mechanical thrombectomy in acute ischemic stroke}

\section{ABSTRACT}

A large number of patients presenting with acute ischemic stroke have large artery intracranial occlusions, and timely recanalization of these occlusions often leads to improved neurologic outcome. Starting with the widespread use of IV tissue plasminogen activator, a wide variety of pharmacologic and mechanical methods have been introduced to improve vessel recanalization and clinical outcome of patients with acute ischemic stroke, which include endovascular therapies such as intra-arterial thrombolytics and mechanical thrombectomy devices. One of the potential therapies is angioplasty and stenting, and this has been evaluated in multiple case reports and small series published by various centers regarding its use in this setting. In this article, we review the current literature on stenting with and without angioplasty, used alone or as a part of multimodal therapy for recanalization for acute cerebrovascular occlusions. Neurology ${ }^{\circledR} 2012 ; 79$ (Suppl 1):S142-S147

\section{GLOSSARY}

AIS = acute ischemic stroke; IA = intra-arterial; IMS = Interventional Management of Stroke; $\mathbf{M E R C I}=$ Mechanical Embolus Removal in Cerebral Ischemia; $\mathbf{m R S}=$ modified Rankin Scale; NIHSS = NIH Stroke Scale; NINDS = National Institute of Neurological Disorders and Stroke; PROACT = Prolyse in Acute Cerebral Thromboembolism; TIMI = thrombolysis in myocardial ischemia; tPA = tissue plasminogen activator.

Stroke is the third most common cause of death in the United States, affecting 700,000 people each year. ${ }^{1}$ Approximately $87 \%$ of these strokes are ischemic, in which a critical reduction in cerebral blood flow leads to brain infarction. ${ }^{1}$ A majority of patients presenting with acute ischemic stroke (AIS) have large artery intracranial occlusions, and timely recanalization of these occlusions often leads to improved neurologic outcome. Starting with the widespread use of IV tissue plasminogen activator (tPA), a wide variety of pharmacologic and mechanical methods have been introduced to improve vessel recanalization and clinical outcome of patients with AIS, which include endovascular therapies such as intra-arterial (IA) thrombolytics and the Merci and Penumbra systems. ${ }^{1-7}$ One of the potential therapies is angioplasty and stenting, and this has been evaluated in multiple case reports and small series published by various centers regarding its use in this setting. Here we review the current literature on stenting, with and without angioplasty, used alone or as a part of multimodal therapy for recanalization for acute cerebrovascular occlusions.

METHODS We performed a MEDLINE/PubMed search of the English-language literature (key words: intracranial stenting, AIS, self-expanding intracranial stent, endovascular therapy, multimodal therapy, mechanical recanalization, stenting and angioplasty, acute cerebrovascular occlusion) and reviewed relevant publications from the period January 1, 2003 to June 30, 2011. The literature search yielded a total of 717 abstracts. For further analysis, we excluded abstracts that dealt with extracranial carotid stenting, mechanical methods except stenting, and stenting when it was done beyond 24 hours of symptom onset for preocclusive or occlusive lesions. Using these criteria, we selected 26 articles for further analysis. After further review, we excluded articles with multimodal therapy in which separate data for angioplasty and stenting were not available. A total of 8 articles were included in our review, with data available for the following: NIH Stroke Scale (NIHSS), time of intervention, type of stent used, periprocedural intracerebral hemorrhage, mortality, and favorable clinical outcome.

From the Departments of Neurology (A.R.X., A.T., A.K.) and Radiology (A.R.X.), Wayne State University, Detroit, MI. Go to Neurology.org for full disclosures. Disclosures deemed relevant by the authors, if any, are provided at the end of this article. 


\begin{tabular}{|c|c|c|c|c|c|c|c|c|c|c|c|c|c|c|}
\hline Table 1 & raphic an & proced & ral charac & eristic & & & & & & & & & & \\
\hline \multirow[b]{2}{*}{$\begin{array}{l}\text { First author, } \\
\text { reference }\end{array}$} & \multirow[b]{2}{*}{$\begin{array}{l}\text { No. of } \\
\text { patients }\end{array}$} & \multirow[b]{2}{*}{ Age, $y$} & \multirow{2}{*}{$\begin{array}{l}\text { NIHSS } \\
\text { (mean or } \\
\text { median) }\end{array}$} & \multicolumn{2}{|c|}{$\begin{array}{l}\text { Lesion } \\
\text { location }\end{array}$} & \multirow[b]{2}{*}{ TTI } & \multirow[b]{2}{*}{ Thrombolytics } & \multirow[b]{2}{*}{$\begin{array}{l}\mathrm{Gp} \\
\|\mathrm{lb} /\| \mathrm{l}\end{array}$} & \multirow[b]{2}{*}{ Mechanical } & \multirow[b]{2}{*}{ Balloon } & \multicolumn{4}{|c|}{$\begin{array}{l}\text { No. of stents } \\
\text { used }\end{array}$} \\
\hline & & & & Ant & Post & & & & & & BMS & w & $\mathrm{N}$ & $E$ \\
\hline Levy et al. (SARIS) $^{17}$ & 20 & 63 & 14 & 17 & 3 & 313 & 5 & 10 & 1 & 8 & & 17 & & 2 \\
\hline Brekenfeld et al. ${ }^{22}$ & 12 & 63 & 14 & 6 & 6 & 393 & 8 & 1 & 4 & 8 & & 12 & & \\
\hline Zaidat et al. ${ }^{23}$ & 9 & 69 & 18 & 8 & 1 & 306 & 7 & 6 & 1 & 8 & & 5 & 4 & \\
\hline Levy et al. ${ }^{24}$ & 19 & 60 & 16 & 15 & 4 & 210 & 16 & 14 & 6 & 13 & 19 & & & \\
\hline Mocco et al. ${ }^{25}$ & 20 & 61.6 & 17 & 18 & 2 & 369 & 10 & 18 & 12 & 7 & & & & 20 \\
\hline $\begin{array}{l}\text { Sauveageau } \\
\text { et al..26 }\end{array}$ & 10 & 72.6 & 16.4 & 10 & & 264 & 4 & 10 & 10 & & 4 & & 6 & \\
\hline Levy et al. ${ }^{27}$ & 18 & 75.1 & 18 & 15 & 3 & NR & 17 & 10 & 9 & 10 & & 3 & 16 & \\
\hline Linfante et al. ${ }^{28}$ & 19 & 64.9 & 19 & 16 & 3 & 385 & 8 & 19 & NR & NR & & 13 & 6 & \\
\hline Total & 127 & & & 105 & 22 & & 75 & 88 & 43 & 54 & 23 & 50 & 32 & 22 \\
\hline Mean & & 66.1 & & & & 320 & & & & & & & & \\
\hline
\end{tabular}

Abbreviations: Ant $=$ anterior circulation; $\mathrm{BMS}=$ balloon-mounted stents; $\mathrm{E}=$ Enterprise; $\mathrm{Gp}=$ glycoprotein; $\mathrm{N}=\mathrm{Neuroform} ; \mathrm{NA}=$ not applicable; $\mathrm{NIHSS}=$ $\mathrm{NIH}$ Stroke Scale score; NR = not reported; Post = posterior circulation; TTI = time to intervention (in minutes); $\mathrm{W}=\mathrm{Wingspan}$.

RESULTS Demographics and lesion characteristics. A total of 127 patients were included, of which 59 $(46.4 \%)$ were men. Mean age $( \pm S D)$ was $66.1 \pm 5.5$ years. Mean time to intervention was $320 \pm 129$ minutes. Mean or median NIHSS scores were reported in the range of 14-19. Anterior circulation was involved in 105 cases $(82.7 \%)$ and posterior circulation in 22 cases (17.3\%) (table 1).

Procedural details. IV, IA, or combined thrombolytic therapy (tPA or urokinase) was used in 75 patients (59\%). A glycoprotein IIb/IIIa inhibitor (eptifibatide or abciximab) was used for $88(69.3 \%)$ of the 127 reported. Prior manipulation with other mechanical therapies, such as the Merci retriever (Concentric Medical, Mountain View, CA), snare devices, an aspiration catheter (Vasco35+, Balt, Montmorency, France), or the Catch thromboembolectomy system (Balt), was used in 43 (33.8\%) of the 108 patients reported (not reported in 1 article; see table 1). Preprocedural or postprocedural balloon angioplasty was performed in $54(50 \%)$ of the 108 patients reported (not reported in 1 article; see table 1). Stent systems used included balloon-mounted coronary stents in 23 patients (18.1\%), Wingspan in 50 (39.4\%), Neuroform (Boston Neurovascular, Fremont, CA) in 32 (25.2\%), and Enterprise (Codman Neurovascular J and J, Boston, MA) in 22 (17.3\%) (table 1).

Successful recanalization, defined as postprocedural Thrombolysis in Myocardial Ischemia (TIMI) grade $2-3$, was achieved in 113 patients (89\%), whereas 14 patients (11\%) had a residual TIMI grade of $0-1$. A total of 26 procedures (20.5\%) had hemorrhagic complication (parenchymal/subarachnoid), of which 12 (9.4\%) were reported as symp- tomatic. Overall mortality was 29.9\% (38/127) (table 2).

Outcome data. Clinical outcome data in these 8 articles were reported as follows: modified Rankin Scale (mRS) score at discharge or at 30 days, mRS score at 90 days, or NIHSS score improvement $\geq 4$. An $\mathrm{mRS}$ score $\leq 3$ at discharge or 30 days was reported in 5 articles, and $48.8 \%$ of the 86 patients had a good outcome. An mRS score $\leq 3$ at 90 days was reported in 3 articles, in a total of 16 (41\%) of 39 patients. One article reported NIHSS score improvement $\geq 4$ occurred in $15(75 \%)$ of 20 patients (table 2 ).

DISCUSSION The combination of angioplasty and stenting has been successfully used for treatment of occlusive coronary lesions in both elective and acute settings. ${ }^{8}$ However, its use in the intracranial circulation is only a decade old, and it has mostly been studied for the treatment of severe intracranial atherosclerotic disease. ${ }^{9}$ The use of intracranial stenting for AIS was introduced as part of multimodal therapy for lesions that were resistant to treatment by other methods of mechanical revascularization. Since then, there have been several case series that have studied the use of this technique in this setting, revealing good recanalization rates, especially for proximal lesions such as carotid $\mathrm{T}$ lesions, which are recalcitrant to recanalization.

Time window. It has been well-established that time to recanalization is one of the most important predictors for improved mortality and morbidity in stroke patients. ${ }^{10}$ Since the National Institute of Neurological Disorders and Stroke (NINDS) trial, IV tPA has 


\begin{tabular}{|c|c|c|c|c|c|c|c|c|c|}
\hline Table 2 & cedural ar & d clinical ou & come & & & & & & \\
\hline Article & $\begin{array}{l}\text { No. of } \\
\text { patients }\end{array}$ & $\begin{array}{l}\text { Post } \\
\text { TIMI/TICI } \\
0-1\end{array}$ & $\begin{array}{l}\text { Post } \\
\text { TIMI/TICI } \\
2-3\end{array}$ & sICH & asICH & Mortality & $\begin{array}{l}\text { NIHSS } \\
\Delta \geq 4\end{array}$ & $\begin{array}{l}\mathrm{mRS} \leq 3 \\
\text { at discharge } \\
\text { or } 30 \mathrm{~d}\end{array}$ & $\begin{array}{l}\mathrm{mRS} \leq 3 \\
\text { at } 90 \mathrm{~d}\end{array}$ \\
\hline $\begin{array}{l}\text { Levy et al. } \\
\text { (SARIS) }^{17}\end{array}$ & 20 & & 20 & 1 & 2 & 5 & NR & 12 & NR \\
\hline $\begin{array}{l}\text { Brekenfeld } \\
\text { et al. } 22\end{array}$ & 12 & 1 & 11 & 0 & 0 & 4 & NR & NA & 6 \\
\hline Zaidat et al. ${ }^{23}$ & 9 & & 8 & 0 & 1 & 3 & NR & NA & 6 \\
\hline Levy et al. ${ }^{24}$ & 19 & 4 & 15 & & 1 & 6 & NR & 9 & NR \\
\hline Mocco et al. ${ }^{25}$ & 20 & 3 & 17 & 2 & 3 & 4 & 15 & NA & NR \\
\hline $\begin{array}{l}\text { Sauveageau } \\
\text { et al. }{ }^{26}\end{array}$ & 10 & 1 & 9 & 3 & 3 & 4 & NR & 3 & NR \\
\hline Levy et al. ${ }^{27}$ & 18 & 4 & 15 & 3 & 4 & 7 & NR & 6 & 4 \\
\hline Linfante et al. ${ }^{28}$ & 19 & 1 & 18 & 3 & 0 & 5 & NR & 12 & NR \\
\hline Total & 127 & 14 & 113 & 12 & 14 & 38 & 15 & 42 & 16 \\
\hline
\end{tabular}

Abbreviations: asICH = asymptomatic intracerebral hemorrhage; $\mathrm{mRS}=$ modified Rankin Scale score; $\mathrm{NA}=$ not applicable; NIHSS $\Delta \geq 4=$ NIH Stroke Scale score improvement of more than 4; NR = not reported; $s I C H$ = symptomatic intracerebral hemorrhage; $\mathrm{TICl}=$ thrombolysis in cerebral infarction; $\mathrm{TIMI}=$ thrombolysis in myocardial infarction.

been the cornerstone of therapy in AIS..$^{10}$ However, even after 15 years of implementation, few AIS patients receive IV tPA. ${ }^{11}$ The recent extension of the time window for administering IV tPA to 4.5 hours will possibly help in increasing the access to this therapy, ${ }^{12}$ but the clinical impact of this extended time window still remains to be seen. Following the NINDS trial, several IA trials (Prolyse in Acute Cerebral Thromboembolism [PROACT] I and II) ${ }^{2,3}$ and trials of combined IA and IV thrombolytics (Interventional Management of Stroke [IMS I and II] $)^{4}$ were conducted, extending the time window of ischemic stroke treatment to 6 hours. Median time to therapy for PROACT II was 5.3 hours, whereas mean time to therapy for the IMS I trial was 217 minutes, or 3 hours and 37 minutes. ${ }^{13}$ Thereafter, mechanical means of recanalization for acute cerebrovascular occlusions such as the Merci retriever ${ }^{5,6}$ and the Penumbra ${ }^{7,13}$ systems further extended the time window for recanalization to 8 hours for the anterior circulation. Median time to recanalization for the pooled data of Mechanical Embolus Removal in Cerebral Ischemia (MERCI) and Multi-MERCI trials was reported to be 4.3 hours for a total of 305 patients. ${ }^{5-7,13}$ In our pooled data for 127 patients, the mean time to recanalization was 320 minutes, or 5 hours and 20 minutes, putting stenting well within the range of the 8-hour window. Current studies are trying to extend this time window for a certain subset of patients, based on the advanced imaging protocol..$^{14}$ As the science of perfusion imaging advances, these windows are bound to advance, which will significantly improve access to thrombectomy therapy for a significant number of stroke patients.

Recanalization rates. Following an acute stroke, recanalization along with the presenting NIHSS score is the best predictor for a good outcome. ${ }^{15}$ Even though IV tPA is the primary mode of therapy for strokes presenting in the first 4.5 hours, recanalization rates with IV thrombolytics have been reported to be only about $10 \%$ in proximal internal carotid artery occlusions and $30 \%$ in middle cerebral artery occlusions. ${ }^{13}$ The use of IA therapy in PROACT I and II advanced these rates to $57.7 \%$ for middle cerebral artery M1 and M2 lesions., ${ }^{73,16}$ However, the use of IA thrombolytics in PROACT I and II was limited to only middle cerebral artery lesions. ${ }^{2,3}$ Combination therapy in IMS I and II achieved rates of thrombolysis in cerebral infarction grade $2-3$ in $61.3 \%$ of cases. ${ }^{7,13,16}$ Use of the Merci retriever with adjunctive therapy further advanced the recanalization rates to $64.6 \%$, and even in lesions of the proximal internal carotid artery the rates were $62.6 \%$. A major gain in the recanalization rates was shown in the use of the Penumbra system, where rates of $81.6 \%$ were observed with the adjunctive use of IA thrombolytic therapy. In our analysis, $89 \%$ of the lesions treated had a recanalization TIMI grade of $2-3$, and in studies published after 2008, this rate was as high as $92.5 \%$, suggesting the possibility that stenting might be superior to other methods of endovascular recanalization.

Postprocedural morbidity and mortality. When compared to the placebo group with a symptomatic intracranial hemorrhage rate of $0.6 \%$, patients receiving IV tPA had a hemorrhage rate of $6.4 \% .{ }^{10}$ The rate following use of IA prourokinase in the PROACT II trial was $10.9 \%$ in the treatment group, ${ }^{3,13}$ whereas in the combined groups of the IMS I and II trials the rates were $6.3 \%$ to $9.9 \% .{ }^{4}$ Data from the MERCI and Multi-MERCI trials had symptomatic intracranial hemorrhage rates of $7.8 \%$ to $9.8 \%$, and this rate increased to $11.2 \%$ with use of the Penumbra Aspira- 
Figure 1 A 71-year-old man presented with dysarthria, imbalance, and weakness

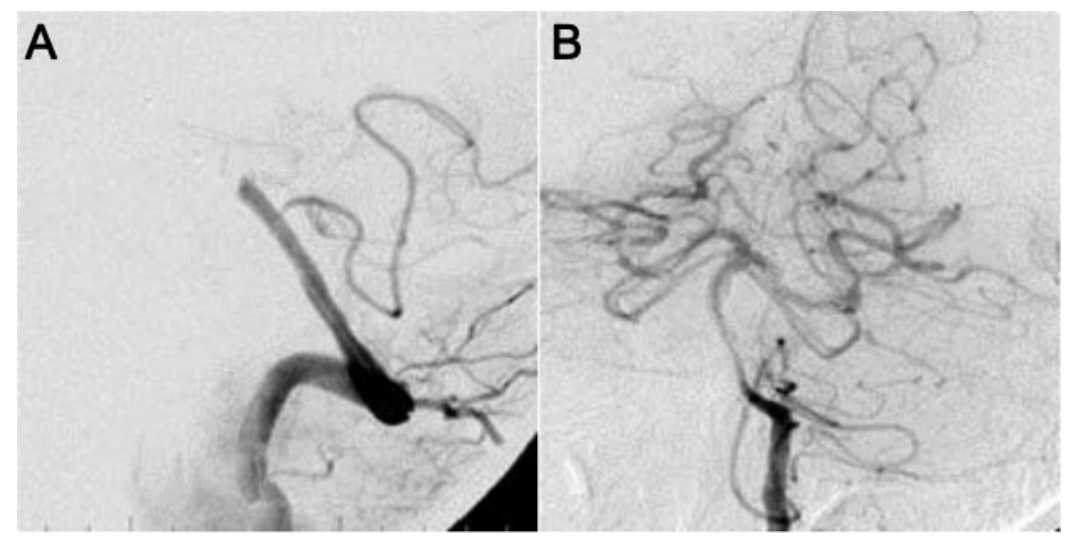

$\mathrm{NIH}$ Stroke Scale score was 12 on presentation. Angiography showed trickle flow in distal basilar artery, with occluded distal vertebral artery (A). Revascularization was done with use of $3.5 \times 12-\mathrm{mm}$ multilink vision and poststenting thrombolysis in cerebral infarction flow was restored to grade 3 (B). Modified Rankin Scale score was 0 at 3 months.

tion System. ${ }^{13}$ In the current pooled analysis we found that this rate was $9.4 \%$.

Another important outcome measure reported in these studies was mortality. The mortality at 3 months for the NINDS placebo group was $24 \% .{ }^{16}$ The mortality rates for various chemical thrombolysis groups, namely, IV tPA, PROACT I, PROACT II, and the IMS I and II trial groups, were $21 \%, 26.9 \%, 25 \%$, and $16 \%$, respectively. ${ }^{7,13,16}$ For the mechanical means the data were reported to be $43.5 \%, 34 \%$, and $32.8 \%$ for the MERCI, Multi-MERCI, and Penumbra systems, respectively. ${ }^{13}$ Mortality in our study group was $30 \%$, comparable to that with other mechanical methods of recanalization.

Favorable clinical outcome. The studies we included did not all report the same outcome variable for clin-

Figure 2 A 42-year-old man presented with right upper- and lower-extremity weakness

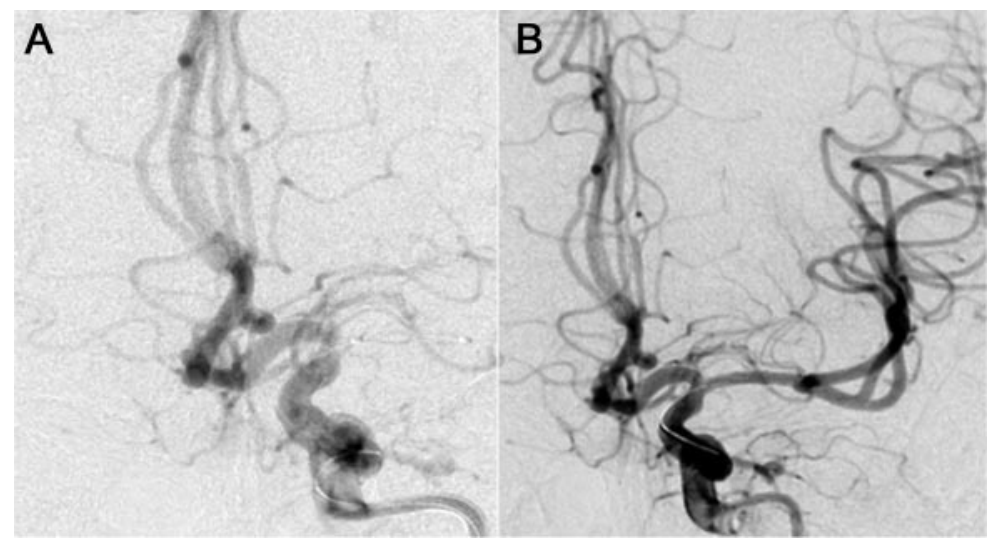

NIH Stroke Scale score was 9. Angiography revealed complete occlusion of left middle cerebral artery M1 (A). Poststenting imaging revealed thrombolysis in cerebral infarction 3 flow grade restoration (B). Modified Rankin Scale score was 0 at discharge. ical outcome, which made comparison to data from other studies difficult. Also, a good functional outcome in most of these studies was defined by an mRS score of $\leq 3$, whereas in all studies including NINDS it was defined by an $\mathrm{mRS}$ score $\leq 2$. Three studies reported data on mRS scores $\leq 3$ only at discharge or 30 days, and in these studies this outcome was achieved in $49 \%$ of patients. Three other studies reported data for the 3-month follow-up, and their pooled results showed an mRS score $\leq 3$ in $41 \%$ of patients. One study reported only a change in NIHSS score by $\geq 4$ points at time of discharge as the good functional outcome measure, and this finding was seen in $75 \%$ of cases in that study. Whereas in the NINDS trial only $33 \%$ of patients had a good functional outcome (mRS scores $\leq 2$ ), ${ }^{10}$ in the IA trials (PROACT and IMS), good functional outcome ( $\mathrm{mRS}$ scores $\leq 2$ ) was achieved in $40 \%$ to $46 \%$ of patients. ${ }^{716}$ Rates from the Multi-MERCI and Penumbra trials were lower; good outcomes (mRS scores $\leq 2$ ) were seen in only $36 \%$ and $25 \%$ of patients, respectively. ${ }^{?}$

The only available prospective trial in our series, the SARIS study by Levy at al., ${ }^{17}$ reveals that a good outcome was noted in $60 \%$ of patients. In a recent article, the study investigators reported 6-month outcome data. A favorable outcome of mRS score $\leq 3$ was seen in $60 \%$ of patients, and an mRS score $\leq 2$ in $55 \%$; mortality at the end of 6 months was $35 \% .{ }^{18}$

Stenting beyond 8 hours (subacute). Recent reports have shown that endovascular therapy including stenting can be done in patients presenting with AIS beyond 8 hours chosen carefully on the basis of diffusion-perfusion-based protocols. ${ }^{14,19}$ These are based on reports that there is salvageable penumbra sustained by collateral support. The recanalization rates reported vary between $90 \%$ and $100 \%$, higher than with most mechanical or chemical methods. ${ }^{20,21} \mathrm{Fa}$ vorable outcomes ( $\mathrm{mRS}$ score $<3$ ) were observed in $50 \%$ to $66 \%$ at 3 months, with postprocedure intracranial hemorrhage/subarachnoid hemorrhage rates of $10 \%$ to $25 \% .^{20,21}$ It is possible that the lesions treated had an underlying atherosclerotic nidus and that stenting helped in stabilizing the endothelium and providing quick and sustained recanalization. Thus, it appears that stenting can be done beyond 8 hours with reliable safety and efficacy in a carefully selected population of patients (figures 1 and 2).

Limitations. There are several important limitations in this review. Most of the studies included are retrospective case series with few patients, except one. We excluded the articles and series where stenting was used as part of multimodal therapy but the role of stenting/angioplasty was not specified separately. 
Even in the articles included in our analysis, stents were used after multiple chemical and mechanical therapies, which makes it difficult to analyze the solitary impact of stenting. Another limitation was that outcome measures defined by these studies were often different, making it difficult to compare these data with other, historical study data. Most of the lesion treatments with stents were done as salvage therapy. This introduces a selection bias in choosing lesions that would be less amenable to other conventional therapies, thus influencing the radiologic and possibly the clinical outcome. In addition, multiple types of stents with different mechanical properties were included, which in turn might have influenced the rates of recanalization and hemorrhage independently.

CONCLUSION A pooled analysis of these data reveals that stenting with angioplasty can be done within a reasonable time and often yields recanalization rates that are quite high. Though incidence of symptomatic intracranial hemorrhage was modest, mortality still continued to be high. We currently find it difficult to pool data on functional outcomes, but most studies report an mRS score $\leq 3$ at discharge or at $1-3$ months for about $41 \%$ to $49 \%$ of patients.

\section{AUTHOR CONTRIBUTIONS}

Dr. Xavier, Dr. Tiwari, and Dr. Kansara all participated in drafting/ revising the manuscript, study concept or design, and analysis or interpretation of data.

\section{ACKNOWLEDGMENT}

The authors acknowledge Mahmoud Rayes, MD; Paritosh Pandey, MD; and Natasha Purai, MD.

\section{DISCLOSURE}

Dr. Xavier has received research support from Concentric Medical, Inc. and receives research support from Medical University of South Carolina (NIH study). Dr. Tiwari and Dr. Kansara report no disclosures. Go to Neurology.org for full disclosures.

Received July 2, 2011. Accepted in final form November 18, 2011.

\section{REFERENCES}

1. Rosamond W, Flegal K, Friday G, et al. Heart disease and stroke statistics: 2007 update: a report from the American Heart Association Statistics Committee and Stroke Statistics Subcommittee. Circulation 2007;115:e69-e171.

2. del Zoppo GJ, Higashida RT, Furlan AJ, et al. PROACT: a phase II randomized trial of recombinant pro-urokinase by direct arterial delivery in acute middle cerebral artery stroke: PROACT Investigators: Prolyse in Acute Cerebral Thromboembolism. Stroke 1998;29:4-11.

3. Furlan A, Higashida R, Wechsler L, et al. Intra-arterial prourokinase for acute ischemic stroke: the PROACT II study: a randomized controlled trial: Prolyse in Acute Cerebral Thromboembolism. JAMA 1999;282:2003-2011.

4. Combined intravenous and intra-arterial recanalization for acute ischemic stroke: the Interventional Management of Stroke Study. Stroke 2004;35:904-911.
5. Smith WS. Safety of mechanical thrombectomy and intravenous tissue plasminogen activator in acute ischemic stroke: results of the Multi Mechanical Embolus Removal in Cerebral Ischemia (MERCI) trial, part I. AJNR Am J Neuroradiol 2006;27:1177-1182.

6. Smith WS, Sung G, Starkman S, et al. Safety and efficacy of mechanical embolectomy in acute ischemic stroke: results of the MERCI trial. Stroke 2005;36:1432-1438.

7. Nogueira RG, Yoo AJ, Buonanno FS, et al. Endovascular approaches to acute stroke, part 2: a comprehensive review of studies and trials. AJNR Am J Neuroradiol 2009;30: $859-875$.

8. Grines CL, Cox DA, Stone GW, et al. Coronary angioplasty with or without stent implantation for acute myocardial infarction: Stent Primary Angioplasty in Myocardial Infarction Study Group. N Engl J Med 1999;341:1949-1956.

9. Zaidat OO, Klucznik R, Alexander MJ, et al. The NIH registry on use of the Wingspan stent for symptomatic 70 99\% intracranial arterial stenosis. Neurology 2008;70: $1518-1524$.

10. The National Institute of Neurological Disorders and Stroke rt-PA Stroke Study Group. Tissue plasminogen activator for acute ischemic stroke. N Engl J Med 1995;333: 1581-1587.

11. Allen NB, Myers D, Watanabe E, et al. Utilization of intravenous tissue plasminogen activator for ischemic stroke: are there sex differences? Cerebrovasc Dis 2009;27:254-258.

12. Hacke W, Kaste M, Bluhmki E, et al. Thrombolysis with alteplase 3 to 4.5 hours after acute ischemic stroke. N Engl J Med 2008;359:1317-1329.

13. Nogueira RG, Schwamm LH, Hirsch JA. Endovascular approaches to acute stroke, part 1: drugs, devices, and data. AJNR Am J Neuroradiol 2009;30:649-661.

14. Natarajan SK, Snyder KV, Siddiqui AH, et al. Safety and effectiveness of endovascular therapy after 8 hours of acute ischemic stroke onset and wake-up strokes. Stroke 2009; 40:3269-3274.

15. Rha JH, Saver JL. The impact of recanalization on ischemic stroke outcome: a meta-analysis. Stroke 2007;38:967-973.

16. Jahan R. Hyperacute therapy of acute ischemic stroke: intraarterial thrombolysis and mechanical revascularization strategies. Tech Vasc Interv Radiol 2005;8:87-91.

17. Levy EI, Siddiqui AH, Crumlish A, et al. First Food and Drug Administration-approved prospective trial of primary intracranial stenting for acute stroke: SARIS (StentAssisted Recanalization in acute Ischemic Stroke). Stroke 2009; 40:3552-3556.

18. Levy EI, Rahman M, Khalessi AA, et al. Midterm clinical and angiographic follow up for the first FDAapproved prospective, single-arm trial of primary stenting for stroke: SARIS (Stent-Assisted Recanalization for acute Ischemic Stroke). Neurosurgery 2011;69: 915-920.

19. Janjua N, El-Gengaihy A, Pile-Spellman J, et al. Late endovascular revascularization in acute ischemic stroke based on clinical-diffusion mismatch. AJNR Am J Neuroradiol 2009;30:1024-1027.

20. Xavier AR, Tiwari A, Purai N, et al. Safety and efficacy of intracranial stenting for acute ischemic stroke beyond $8 \mathrm{~h}$ of symptom onset. J NeuroIntervent Surg Epub 2011 April 28.

21. Kansara A, Pandey P, Tiwari A, et al. Stenting of acute and subacute intracranial vertebrobasilar arterial occlusive lesions. J NeuroIntervent Surg Epub 2011 June 29. 
22. Brekenfeld C, Schroth G, Mattle HP, et al. Stent placement in acute cerebral artery occlusion: use of a selfexpandable intracranial stent for acute stroke treatment. Stroke 2009;40:847-852.

23. Zaidat OO, Wolfe T, Hussain SI, et al. Interventional acute ischemic stroke therapy with intracranial selfexpanding stent. Stroke 2008;39:2392-2395.

24. Levy EI, Ecker RD, Horowitz MB, et al. Stent-assisted intracranial recanalization for acute stroke: early results. Neurosurgery 2006;58:458-463.

25. Mocco J, Hanel RA, Sharma J, et al. Use of a vascular reconstruction device to salvage acute ischemic occlusions refractory to traditional endovascular recanalization methods. J Neurosurg 2010;112:557-562.

26. Sauvageau E, Samuelson RM, Levy EI, et al. Middle cerebral artery stenting for acute ischemic stroke after unsuccessful Merci retrieval. Neurosurgery 2007;60:701-706.

27. Levy EI, Mehta R, Gupta R, et al. Self-expanding stents for recanalization of acute cerebrovascular occlusions. AJNR Am J Neuroradiol 2007;28:816-822.

28. Linfante I, Samaniego EA, Geisbusch P, et al. Selfexpandable stents in the treatment of acute ischemic stroke refractory to current thrombectomy devices. Stroke 2011; 42:2636-2638. 


\section{Neurology}

\section{Angioplasty and stenting for mechanical thrombectomy in acute ischemic stroke Andrew R. Xavier, Ambooj Tiwari and Amit Kansara \\ Neurology 2012;79;S142-S147 \\ DOI 10.1212/WNL.0b013e3182695896}

This information is current as of September 24, 2012

\section{Updated Information \& Services}

References

Subspecialty Collections

Permissions \& Licensing

Reprints including high resolution figures, can be found at: http://n.neurology.org/content/79/13_Supplement_1/S142.full

This article cites 26 articles, 14 of which you can access for free at: http://n.neurology.org/content/79/13_Supplement_1/S142.full\#ref-list1

This article, along with others on similar topics, appears in the following collection(s):

\section{All Cerebrovascular disease/Stroke}

http://n.neurology.org/cgi/collection/all_cerebrovascular_disease_strok e

Information about reproducing this article in parts (figures,tables) or in its entirety can be found online at:

http://www.neurology.org/about/about_the_journal\#permissions

Information about ordering reprints can be found online:

http://n.neurology.org/subscribers/advertise

Neurology ${ }^{\circledR}$ is the official journal of the American Academy of Neurology. Published continuously since 1951, it is now a weekly with 48 issues per year. Copyright Copyright (? 2012 by AAN Enterprises, Inc.. All rights reserved. Print ISSN: 0028-3878. Online ISSN: 1526-632X.

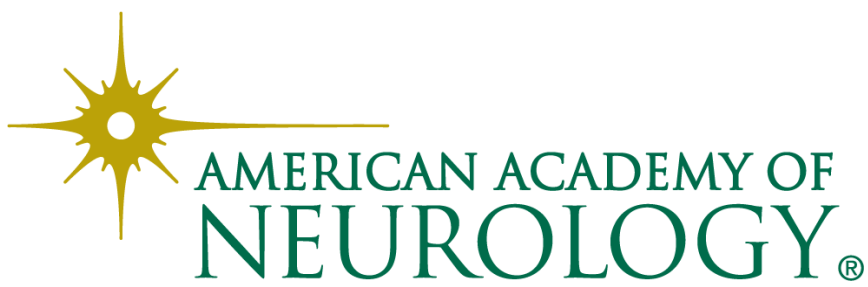

